\title{
Phase I Clinical and Pharmacokinetic Study of PM01183 (a tetrahydroisoquinoline, Lurbinectedin) in Combination with Gemcitabine in Patients with Advanced Solid Tumors
}

Luis Paz-Ares ${ }^{\text {a,e }}$, Martin Forster ${ }^{\text {b }}$, Valentina Boni ${ }^{c}$, Sergio Szyldergemajn ${ }^{\text {d }}$, Jesús Corral a, Samantha Turnbull b,f, Antonio Cubillo ${ }^{\mathrm{c}}$, Carlos Fernandez Teruel d, Iker López Calderero ${ }^{\mathrm{a}, \mathrm{g}}$, Mariano Siguero ${ }^{\mathrm{d}}$, Patrick Bohan ${ }^{\mathrm{d}}$, Emiliano Calvo ${ }^{\mathrm{c}}$ *

${ }^{\text {a }}$ Hospital Universitario Virgen del Rocío, Seville, Spain

${ }^{\mathrm{b}}$ University College of London Hospital, London, UK

${ }^{c}$ START Madrid, Centro Integral Oncológico Clara Campal, Hospital Universitario Madrid Sanchinarro, Madrid, Spain

${ }^{\text {d }}$ Pharma Mar, S.A., Colmenar Viejo, Madrid, Spain

${ }^{\mathrm{e}}$ Present address: Chair of the Medical Oncology Department, Hospital Universitario 12 de Octubre, Madrid, Spain

${ }^{\mathrm{f}}$ Present address: Clinical Research Fellow and SpR in Medical Oncology, Leeds Immunotherapy Team (LIT) at the Leeds Institute of Cancer and Pathology, University of Leeds, Leeds, UK

${ }^{g}$ Present address: Consultant Clinical Oncologist in Can Misses Hospital, Ibiza, Spain

\section{* Correspondence to:}

Emiliano Calvo MD, PhD START Madrid, Centro Integral Oncológico Clara Campal, Hospital Universitario Madrid Sanchinarro, Madrid, Spain

Emiliano.Calvo@start.stoh.com 


\section{ACKNOWLEDGEMENTS}

Support was provided to Martin Forster by the National Institute for Health Research, the University College London Hospitals Biomedical Research Centre, and the Cancer Research UK University College London Experimental Cancer Medicine Centre. 


\section{ABSTRACT}

Background: To determine the recommended dose (RD) of a combination of PM01183 and gemcitabine in patients with advanced solid tumors.

Methods: Forty-five patients received escalating doses of PM01183/gemcitabine on Days 1 and 8 every 3 weeks (d1,8 q3wk) following a standard 3+3 design.

Results: PM01183 $3.5 \mathrm{mg}$ flat dose (FD)/gemcitabine $1000 \mathrm{mg} / \mathrm{m}^{2}$ was the highest dose level tested. Dose-limiting toxicities (DLTs) were mostly hematological and resulted in the expansion of a lower dose level (PM01183 $3.5 \mathrm{mg}$ FD/gemcitabine $800 \mathrm{mg} / \mathrm{m}^{2}$ ); 19 patients at this dose level were evaluable but $>30 \%$ had DLT and $>20 \%$ had febrile neutropenia. No DLT was observed in 11 patients treated at PM01183 $3.0 \mathrm{mg}$ FD/gemcitabine $800 \mathrm{mg} / \mathrm{m}^{2}$, which was defined as the RD. This regimen was feasible and tolerable with manageable toxicity; mainly grade 3/4 myelosuppression. Nonhematological toxicity comprised fatigue, nausea, vomiting, and transaminases increases. Fifteen (33\%) patients received $\geq 6$ cycles with no cumulative hematological toxicity. Pharmacokinetic analysis showed no evidence of drug-drug interaction. Nine of 38 patients had response as per RECIST (complete [3\%] and partial [21\%]), for an overall response rate (ORR) of 24\% (95\% Confidence Interval [CI] 12-40\%). Eleven patients $(29 \%)$ had disease stabilization $\geq 4$ months. Responses were durable (median of 8.5 months): overall median progression-free survival (PFS) was 4.2 months (95\% CI, 2.7-6.5 months).

Conclusions: The RD for this combination is PM01183 $3.0 \mathrm{mg}$ FD (or 1.6 $\left.\mathrm{mg} / \mathrm{m}^{2}\right) /$ gemcitabine $800 \mathrm{mg} / \mathrm{m}^{2} \mathrm{~d} 1,8 \mathrm{q} 3 \mathrm{wk}$. This schedule is well tolerated and has antitumor activity in several advanced solid tumor types.

Key words: PM01183, lurbinectedin, gemcitabine, combination, solid tumor. 


\section{INTRODUCTION}

PM01183 (lurbinectedin) is a synthetic tetrahydroisoquinoline with broad in vitro and in vivo anticancer cytotoxic activity. Its hemiaminal moiety forms a covalent bond with the exocyclic amino group of specific guanines in the minor groove of DNA [1,2]. Highlyspecific hydrogen bonds with the nucleotides at both sides of the guanine determine its sequence specificity. PM01183-DNA adducts degrade the largest subunit of RNA polymerase II (Rpb1) via the ubiquitin-proteasome pathway and inhibit the nucleotideexcision repair (NER) system [3,4]. PM01183 also inhibits transcription by binding to CG-rich sequences, mainly located around promoters of protein-coding genes [5] and causes DNA damage that delays progression through the S/G2 phase of the cell cycle and induces caspase-dependent apoptotic death [6-8]. PM01183 combined with gemcitabine has shown synergism in preclinical models, particularly in pancreatic ductal adenocarcinoma (PDA) xenografts [9]. This synergism is the result of enhanced DNA damage induced by both drugs, and of the selective depletion of tumor-associated macrophages (TAMs) by PM01183 in the tumor stroma. This depletion in turn down regulates cytidine deaminase $(\mathrm{CDA}$, an enzyme that catabolizes gemcitabine into its inactive metabolite difluorodeoxyuridine $[\mathrm{dFdU}]$ ) and thus increases the effect of gemcitabine. This effect may be particularly relevant in high-density TAM tumors, which have been associated with poor prognosis and higher risk of metastasis [10,11].

The first-in-human $(\mathrm{FiH})$ study defined a recommended dose (RD) of $4.0 \mathrm{mg} / \mathrm{m}^{2}$ (equivalent to $7.0 \mathrm{mg}$ flat dose [FD]) for PM01183 given as a 1-h intravenous (i.v.) infusion every 3 weeks ( $\mathrm{q} 3 \mathrm{wk}$ ) to advanced cancer patients [12]. Predictable and reversible severe myelosuppression, particularly neutropenia, was the limiting toxicity. A Day 1 and $8(\mathrm{~d} 1,8)$ q3wk schedule was subsequently tested in advanced cancer patients, with similar results at a RD of $5.0 \mathrm{mg}$ FD (or $2.8 \mathrm{mg} / \mathrm{m}^{2}$ ) [13]. 
Pharmacokinetic (PK) data from the FiH study showed that PM01183 has a relatively short half-life $(62.7 \mathrm{~h})$ and high inter-patient variability (coefficient of variation $[\mathrm{CV}]$ of $72.6 \%)$ at the RD [12].

This phase I trial was conducted to determine the RD of PM01183 in combination with gemcitabine in patients with advanced solid tumors. The starting PM01183 dose, $2.5 \mathrm{mg}$ FD, is equivalent to $50 \%$ of the RD for single-agent PM01183 administered d1,8 q3wk. This schedule is also commonly used with gemcitabine and provides an adequate frame for avoiding any significant drug accumulation. The starting gemcitabine dose was $800 \mathrm{mg} / \mathrm{m}^{2}$ and could be escalated to $1000 \mathrm{mg} / \mathrm{m}^{2}$ (its full dose in most combinations) if a PM01183 FD of $3.5 \mathrm{mg}$ was found to be feasible.

\section{MATERIALS AND METHODS}

The study (NCT number NCT01970553, EudraCT number 2010-024239-18) was conducted in Spain and the UK at 3 investigational sites following International Conference on Harmonization (ICH) Good Clinical Practice guidelines, and was approved by the respective Research Ethics Committees. Informed consent was obtained from all individual participants included in the study.

\section{Eligibility Criteria}

Selection criteria included: age 18-75 years; histologically/cytologically confirmed diagnosis of advanced malignant disease; $\leq 2$ prior lines of cytotoxic-containing chemotherapy for advanced disease; life expectancy $\geq 3$ months; recovery from previous toxicities to grade $\leq 1$ (grade $\leq 2$ for alopecia, cutaneous toxicity peripheral sensory neuropathy, fatigue); Eastern Cooperative Oncology Group performance status (ECOG PS) $\leq 1$; normal left ventricular ejection fraction (LVEF); and adequate bone marrow, 
hepatic, renal, and metabolic function.

Criteria for exclusion were: prior treatment with PM01183 or with gemcitabinecontaining therapy for advanced disease (adjuvant therapy was allowed if $\leq 6$ cycles were administered and relapse occurred at $>6$ months); symptomatic progressive or corticosteroid-requiring brain metastases or leptomeningeal involvement; pregnancy or lactation; radiotherapy to $>35 \%$ of bone marrow; concomitant conditions such as unstable angina, myocardial infarction, congestive heart failure, or clinically significant valvular heart disease, symptomatic or uncontrolled arrhythmia requiring treatment, chronic hepatopathy, active uncontrolled infection, known human immunodeficiency virus (HIV) infection; and a history of prior bone marrow or stem cell transplantation.

\section{Study Treatment}

PM01183 was supplied by Pharma Mar, S.A. (Colmenar Viejo, Madrid, Spain) as a 1.0 $\mathrm{mg} / \mathrm{vial}$ of lyophilized powder concentrate for solution for infusion. It was administered in escalating doses as a 1-h i.v. infusion d1,8 q3wk. Gemcitabine vials (Gemzar ${ }^{\circledR} 1000$ $\mathrm{mg}$ and $200 \mathrm{mg}$ ) were administered as a 30-min i.v. infusion prior to each PM01183 administration.

Patients received standard antiemetic prophylaxis before each administration (steroids with serotonin antagonists). Treatment was administered until: disease progression; unacceptable toxicity; treatment delay $>15$ days due to toxicity (except in cases of obvious patient benefit); failure to meet retreatment criteria; or requirement of $>2$ dose reductions.

\section{Dose Escalation and Dose-limiting Toxicities}

Dose escalation followed a standard 3+3 design. Dose-limiting toxicities (DLTs) were 
any of the following events in Cycle 1: grade 4 neutropenia (absolute neutrophil count $<0.5 \times 10^{9} / \mathrm{L}$ ) lasting $>7$ days; febrile neutropenia of any duration or neutropenic sepsis; grade 4 thrombocytopenia (platelet count $<25 \times 10^{9} / \mathrm{L}$ ) or grade 3 with bleeding requiring a platelet transfusion; grade 4 alanine aminotransferase (ALT) or aspartate aminotransferase (AST) increase, or grade 3 lasting >14 days; treatment-related grade $\geq 2$ ALT/AST increase concomitantly with $\geq 2 \times$ upper limit of normal (ULN) total bilirubin increase and normal alkaline phosphatase (ALP); grade $\geq 3$ creatine phosphokinase increase; any other grade $\geq 3$ non-hematological adverse event (AE) suspected to be related to study drugs; delay $>15$ days in the administration of Cycle 2 due to any AE related to study drugs. Toxicities occurring after Cycle 1 or noncompliance with the intended dose intensity could also qualify as DLT. The RD was defined as the highest dose level at which less than one third of evaluable patients had DLT.

\section{Study Assessments}

Patients were assessed (physical examination, ECOG PS, laboratory tests) at baseline, before infusions and at the start of each new cycle. Any clinically-relevant grade $\geq 3$ abnormalities were reassessed every $2-3$ days until recovery to grade $\leq 1$. Febrile neutropenia, grade 4 neutropenia, and grade 4 thrombocytopenia were reassessed daily until recovery to grade $\leq 3$ or fever resolution, and then every 2-3 days until recovery to grade $\leq 1$. Antitumor activity was evaluated radiologically by contrast-enhanced helical computed tomography scan or magnetic resonance imaging every 2 cycles (6 weeks).

\section{Pharmacokinetics}


Fifteen samples were collected to quantify PM01183 plasma concentrations at baseline and during the week after the first PM01183 infusion; two more samples on Day 15 and Day 22 were collected for the analysis of PM01183 after the Day-8 infusion. PM01183 was measured by mean of a validated liquid extraction method followed by ultraperformance liquid chromatography tandem mass-spectrometry (UPLC-MS/MS) detection. The calibration range for PM01183 was $0.1-50 \mathrm{ng} / \mathrm{mL}$. Fifteen samples were also collected to quantify gemcitabine and its metabolite, $\mathrm{dFdU}$, at baseline and during the two days after the end of the first gemcitabine infusion. Gemcitabine and dFdU concentrations were measured by a validated method using high performance liquid chromatography mass spectrometry (HPLC-MS/MS). The calibration ranges were 45.57-12570.20 ng/mL and 99.45-12570.20 ng/mL for gemcitabine and dFdU, respectively.

\section{Statistical Analysis}

The numbers of patients included, evaluable for DLT, safety, and efficacy were summarized by dose level. Safety was evaluated using descriptive statistics. Laboratory abnormalities and AEs were graded according to the National Cancer Institute Common Terminology Criteria for Adverse Events (NCI-CTCAE) v 4.03. Antitumor activity was evaluated using the Response Evaluation Criteria in Solid Tumors (RECIST) v 1.1. Response rates were characterized using descriptive statistics (95\% exact binomial confidence interval $[\mathrm{CI}])$. Overall response rate (ORR) included complete $(\mathrm{CR})$ and partial responses (PR). Patients with clinical benefit were those with CR, PR and stable disease (SD) $\geq 4$ months.

Statistical analyses were performed using SAS v 9.2, (SAS Institute Inc, Cary, NC, USA) and non-compartmental analysis (NCA) using Phoenix WinNonlin v 6.3 
(Certara USA Inc, Princeton, NJ, USA). All tests were two-sided; significance was set at 0.05 . The $\mathrm{CV}$ was defined as the ratio of the standard deviation to the mean.

\section{RESULTS}

\section{Patient Characteristics and Treatment}

Forty-five patients were treated between May 2011 and May 2013. Patient characteristics are shown in Table 1. A total of 203 cycles were administered, with a median of 3 cycles per patient (range, 1-17 cycles). Fifteen patients (33\%) received 6 cycles or more. At the RD, 56 cycles were administered to 11 patients: median number of cycles per patient was 4 (range, 2-11 cycles).

\section{Dose-limiting Toxicities and Recommended Dose}

DLT was observed at 2 of the 4 dose levels tested (Table 2). At the highest dose level (PM01183 $3.5 \mathrm{mg}$ FD/gemcitabine $1000 \mathrm{mg} / \mathrm{m}^{2}$ ), DLT occurred in 4 of 6 evaluable patients (67\%): grade 4 thrombocytopenia $(n=2)$; grade 4 neutropenic infection; grade 4 febrile neutropenia; grade 5 neutropenic sepsis; and omission of Day 8 infusions in several cycles due to treatment-related myelosuppression ( $\mathrm{n}=1$ each).

At the immediately lower dose level (PM01183 $3.5 \mathrm{mg}$ FD/gemcitabine 800 $\mathrm{mg} / \mathrm{m}^{2}$ ), DLT were found in 6 of 19 evaluable patients (32\%): grade 3/4 febrile neutropenia $(n=5)$; grade 4 thrombocytopenia $(n=4)$; and grade 4 hemoptysis that resulted in death $(n=1)$. This dose level was considered unfeasible due to the number and severity of DLT and to the rate of febrile neutropenia (>20\%).

No DLT occurred in 11 patients treated at the next lower dose level (PM01183 $3.0 \mathrm{mg} \mathrm{FD} /$ gemcitabine $800 \mathrm{mg} / \mathrm{m}^{2}$ ), which therefore was confirmed as the RD. The PM01183 dose of $3.0 \mathrm{mg}$ FD corresponds to $1.6 \mathrm{mg} / \mathrm{m}^{2}$ (i.e., $3.0 \mathrm{mg}$ FD divided by 1.9 
$\mathrm{m}^{2}$, the median body surface area [BSA] at the RD in this study). At the RD this schedule was feasible, with acceptable compliance, and delivered the intended dose intensity without excessive dose delays. Primary granulocyte-colony stimulating factor (G-CSF) prophylaxis was not required according to current guidelines [14], as only one of 11 patients (9\%) had febrile neutropenia at the RD.

\section{Toxicity Profile}

Myelosuppression was the most frequent abnormality at the RD (Table 3). The most common severe hematological abnormalities were neutropenia (55\% of patients/36\% of cycles) and thrombocytopenia (27\% of patients/7\% of cycles). Grade 4 neutropenia (46\% of patients $/ 18 \%$ of cycles) lasted a median of 3.5 days (range, $2-5$ days) and was controlled by dose reduction or secondary G-CSF prophylaxis; median time-to-nadir was 15 days (range, $7-24$ days).

G-CSF support showed a clear dose relationship: it was given to $40 \%$ of patients at all dose levels, to $27 \%$ at the RD, and to $43 \%$ and $56 \%$ at the 2 dose levels above the RD. Nineteen patients required red blood cell transfusions: 2 (11\%) below the RD, (37\%) at the $\mathrm{RD}$ and $10(53 \%)$ above the $\mathrm{RD}$. Nine patients required platelets transfusions: one $(11 \%)$ at the RD and $8(89 \%)$ above the RD.

The most common biochemical abnormalities at the RD were increases in transaminase and creatinine levels (Table 3). Most were mild or moderate, and none reached grade 4 . Grade 3 abnormalities comprised ALT increase (18\% of patients/4\% of cycles), and AST and ALP increase (9\% of patients/2\% of cycles each). Of note, grade 3 transaminases increases with gemcitabine $1000 \mathrm{mg} / \mathrm{m}^{2}$ were almost twice more frequent than with $800 \mathrm{mg} / \mathrm{m}^{2}$. 
At the $\mathrm{RD}$, the most common treatment-related AEs were fatigue (64\% of patients $/ 39 \%$ of cycles), nausea (55\% of patients/21\% of cycles) and vomiting (36\% of patients/11\% of cycles) despite antiemetic prophylaxis (Table 3). Most of these AEs were mild or moderate, and none reached grade 4 . Grade 3 AEs consisted only of single episodes of rash (associated with gemcitabine), febrile neutropenia, and fatigue. No unexpected toxicity was observed, and the frequency of gemcitabine-related AEs was no higher than expected. Only one patient at the RD discontinued treatment due to a related $\mathrm{AE}$ (grade 3 fatigue after 11 cycles, while having complete response). No treatment-related deaths occurred at the RD.

\section{Efficacy}

Thirty-eight treated patients were evaluable according to RECIST v 1.1. One CR (3\%) and 8 PRs (21\%) were observed at all dose levels (ORR=24\%; 95\%CI, 12-40\%). Furthermore, 21 SDs (55\%) were found, with 11 patients (29\%) having SD $\geq 4$ months. Responses lasted a median of 8.5 months, and 7 were confirmed radiologically. Median PFS was 4.2 months (95\%CI, 2.7-6.5 months). The PM01183/gemcitabine combination showed antitumor activity across most tumor types, particularly non-small cell lung cancer (NSCLC) $(\mathrm{ORR}=29 \%, 95 \% \mathrm{CI}, 10-56 \%)$ and ovarian cancer $(\mathrm{ORR}=40 \%$, 95\%CI, 5-85\%) (Table 4).

\section{Pharmacokinetics}

All patients were sampled for PK analysis but 5 patients had high PM01183 and gemcitabine concentrations and could not be included in the NCA analysis; all dFdU concentrations were adequately quantified. PM01183 had lineal PK, with no trend to increase or decrease with dose. Mean (standard deviation) total body clearance (CL) 
results were 11.5 (6.0), 13.4 (8.2), 11.6 (5.7) for PM01183 2.5, 3.0 (RD), 3.5 mg FD plus gemcitabine $800 \mathrm{mg} / \mathrm{m}^{2}$, respectively, and 9.4 (5.3) for PM01183 $3.5 \mathrm{mg}$ FD plus gemcitabine $1000 \mathrm{mg} / \mathrm{m}^{2}$ (Table 5). The mean (standard deviation) BSA dose corresponded to $1.7(0.2) \mathrm{mg} / \mathrm{m}^{2}$ at the RD. A similar mean (standard deviation) CL, 12.5 (7.1) $\mathrm{L} / \mathrm{h}$, was found at the $\mathrm{RD}$ in the $\mathrm{FiH}$ study, thus suggesting that gemcitabine did not affect the PK profile of PM01183 [12].

No significant differences were found between plasma PM01183 concentrations on Day 8 and Day 15, suggesting that drug accumulation is unlikely. Most patients (91\%) had non-quantifiable PM01183 plasma concentrations on Day 22 of Cycle 1. No dose exposure relationship was observed in Cycle 1 using the dose versus area under the curve (AUC) and maximum plasma concentration $\left(\mathrm{C}_{\max }\right)$ in Cycle 1, probably because of large interpatient variability and the similarity of the dose levels explored.

Gemcitabine PK was similar to that reported for gemcitabine alone or in combination, with a mean half-life of $0.2 \mathrm{~h}$. At the RD, mean half-life and AUC for $\mathrm{dFdU}$ were $20.3 \mathrm{~h}$ and $277.0 \mathrm{~h} * \mu \mathrm{g} / \mathrm{mL}$, respectively. These values were higher than those reported in other studies, maybe because the last sample with quantifiable $\mathrm{dFdU}$ concentrations in the present study was collected $48 \mathrm{~h}$ after infusion, while in other studies it was collected close to $24 \mathrm{~h}$ after infusion [15-17]. The mean (standard deviation) CL of dFdU at the RD in this study was 5.6 (1.4) L/h (Table 5). Therefore, PM01183 did not seem to affect the PK of gemcitabine or dFdU.

Nadir and baseline neutrophil and platelet values in Cycle 1 were also evaluated: neutropenia was not related to PM01183 AUC but was related to dFdU AUC ( $\mathrm{p}<0.05)$. Thrombocytopenia was not found to be related to exposure. Finally, PFS was not found to be linked to either PM01183 or dFdU AUC. 


\section{DISCUSSION}

Myelosuppression was the most frequent and relevant toxicity observed with the PM01183/gemcitabine combination in this study, and showed a clear dose relationship. At the RD (PM01183 $3.0 \mathrm{mg}$ FD/gemcitabine $800 \mathrm{mg} / \mathrm{m}^{2}$ ), this combination delivered $80 \%$ of the standard gemcitabine combination dose $\left(1000 \mathrm{mg} / \mathrm{m}^{2}\right)$ and $60 \%$ of the RD for single-agent PM01183 (5.0 mg FD) in d1,8 q3wk schedules [13,18,19]. Patients in this study did not require primary G-CSF prophylaxis, but they had adequate bone marrow function at baseline. Furthermore, patients aged $>75$ years, ECOG PS $>1$, and $>2$ prior chemotherapy-containing lines had been excluded from the study.

The antitumor activity observed with the PM01183/gemcitabine combination in this study provides proof-of-concept and justifies further evaluation in prospectivelydefined settings. Gemcitabine has shown activity in breast, pancreatic, ovarian, and NSCLC, with ORRs of 10-48\% [20-23]. For most tumors in this study, the ORR with the combination is slightly higher than that found with gemcitabine alone, although the small sample size resulted in wide confidence intervals. The responses observed in NSCLC (one CR and 4 PR among 19 patients; ORR=29\%, 95\% CI, 10-56\%) compares favorably with second-line cytotoxics such as docetaxel or pemetrexed (with ORRs usually below 8\%) [24]. Late therapies for both squamous and non-squamous NSCLC comprise mutation-driven strategies and immune checkpoint inhibitors, but second- and later line strategies are still needed [25,26].

PM01183 has shown single-agent activity in platinum-resistant ovarian cancer patients $(\mathrm{ORR}=30 \%$; 95\% CI, 16-49\%) and in BRCA-1 or 2 germline mutation breast cancer $(\mathrm{ORR}=40 \% ; 95 \%$ CI $25-57 \%)$ in previous studies $[27,28]$. In this study, antitumor activity was observed both in platinum-resistant ovarian cancer ( 2 PR and one $\mathrm{SD} \geq 4$ months) and in metastatic breast cancer (one PR and $3 \mathrm{SD} \geq 4$ months in 2 
patients with triple-negative disease and 2 with hormone receptor positive/HER negative disease). PM01183, gemcitabine, and dFdU PK findings were similar to results from single-agent trials and no drug-drug interaction was suggested. This was expected as PM01183 has a very low urine excretion ( $<1 \%$ recovery dose after i.v. infusion) and is probably metabolized in the liver and $\mathrm{dFdU}$ is excreted in urine and its elimination depends on renal function.

Myelosuppression is a common toxicity for both PM01183 and gemcitabine. In this trial, however, no relationship between AUC and observed neutropenia was established probably because PK data for NCA were only available for Day 1 of Cycle 1, because of AUC variability, and because of the similarity of the dose levels explored. On the other hand, dFdU exposure was seen to be related to neutropenia (but not to thrombocytopenia). For the same reasons, PK data did not establish a relationship with efficacy results.

In summary, the RD for the combination is PM01183 $3.0 \mathrm{mg}$ FD (or 1.6 $\left.\mathrm{mg} / \mathrm{m}^{2}\right) /$ gemcitabine $800 \mathrm{mg} / \mathrm{m}^{2} \mathrm{~d} 1,8 \mathrm{q} 3 \mathrm{wk}$. This schedule is feasible with manageable and non-cumulative myelosuppression (mostly severe neutropenia with or without severe thrombocytopenia) and active in several tumors, such as NSCLC, ovarian, and breast cancer. Further research is warranted to clarify further its potential in the treatment of these tumors.

\section{COMPLIANCE WITH ETHICAL STANDARDS}

\section{Conflict of interest}

Emiliano Calvo, Martin Forster, Valentina Boni, Jesús Corral, Samantha Turnbull, Antonio Cubillo, and Iker López Calderero declare that they have no conflict of interest. Luis Paz-Ares reports honoraria from Pharma Mar, S.A. outside the submitted work. 
Sergio Szyldergemajn, Carlos Fernandez Teruel and Patrick Bohan are employees of Pharma Mar, S.A. Mariano Siguero is an employee and shareholder of Pharma Mar, S.A.

\section{Funding}

This work was funded by a grant from Pharma Mar, S.A.

\section{Ethical Approval}

All procedures performed in studies involving human participants were in accordance with the ethical standards of the institutional and/or national research committee and with the 1964 Helsinki declaration and its later amendments or comparable ethical standards.

\section{Informed Consent}

Informed consent was obtained from all individual participants included in the study. 


\section{REFERENCES}

1. Leal JF, Martinez-Diez M, Garcia-Hernandez V, Moneo V, Domingo A, BuerenCalabuig JA, Negri A, Gago F, Guillen-Navarro MJ, Aviles P, Cuevas C, GarciaFernandez LF, Galmarini CM (2010) PM01183, a new DNA minor groove covalent binder with potent in vitro and in vivo anti-tumour activity. $\mathrm{Br} \mathrm{J}$ Pharmacol 161 (5): 1099-1110

2. Bueren-Calabuig JA, Giraudon C, Galmarini CM, Egly JM, Gago F (2011) Temperature-induced melting of double-stranded DNA in the absence and presence of covalently bonded antitumour drugs: insight from molecular dynamics simulations. Nucleic acids research 39 (18):8248-8257. doi:10.1093/nar/gkr512

3. Santamaria G, Martínez-Leal JF, Cuevas C, Garcia-Fernandez LF, Galmarini CM 47 Lurbinectedin (PM01183) specifically targets RNA Pol II for degradation via the proteasome pathway in a transcription and TC-NER dependent fashion. European Journal of Cancer 50:20-21. doi:10.1016/S0959-8049(14)70173-X

4. Soares DG, Machado MS, Rocca CJ, Poindessous V, Ouaret D, Sarasin A, Galmarini CM, Henriques JA, Escargueil AE, Larsen AK (2011) Trabectedin and its C subunit modified analogue PM01183 attenuate nucleotide excision repair and show activity toward platinum-resistant cells. Molecular cancer therapeutics 10 (8):1481-1489. doi:10.1158/1535-7163.MCT-11-0252

5. Santamaria Nunez G, Robles CM, Giraudon C, Martinez-Leal JF, Compe E, Coin F, Aviles P, Galmarini CM, Egly JM (2016) Lurbinectedin Specifically Triggers the Degradation of Phosphorylated RNA Polymerase II and the Formation of DNA Breaks in Cancer Cells. Molecular cancer therapeutics. doi:10.1158/1535-7163.mct-16-0172

6. Guillen MJ, Cataluña O, Palomares M, Lopez R, Cuevas C, Aviles P (2011) In vivo combination studies of PM01183 with alkylating, antimetabolites, DNA-topoisomerase inhibitors and tubulin binding agents. Cancer Res 71 (8 Suppl):Abstract 3538

7. Soares DG, Larsen AK, Escargueil AE (2012) The DNA damage response to monofunctional anticancer DNA binders. Drug Discov Today 9 (2):59-67

8. Aviles P, Galmarini C, Cuevas C, Guillen MJ, Frapolli R, Uboldi S, Romano M, Tavecchio M, Erba E, Bello E, D'Incalci M (2009) Mechanism of action and antitumor activity of PM01183. Cancer Res 69 (9 Suppl):Abstract 2679

9. Mangues R, Céspedes MV, Guillén MJ, Alamo P, López R, Gallardo A, Nuñez P, Cuevas C, Aviles P 223 Lurbinectedin (PM01183) Synergizes with Gemcitabine in NSCLC, Ovarian and Pancreas Tumor Xenografts. European Journal of Cancer 48:6768. doi:10.1016/S0959-8049(12)72021-X

10. Cespedes MV, Guillen MJ, Lopez-Casas PP, Sarno F, Gallardo A, Alamo P, Cuevas C, Hidalgo M, Galmarini CM, Allavena P, Aviles P, Mangues R (2016) Lurbinectedin induces depletion of tumor-associated macrophages (TAM), an essential component of its in vivo synergism with gemcitabine. Dis Model Mech. doi:10.1242/dmm.026369

11. Heusinkveld M, van der Burg SH (2011) Identification and manipulation of tumor associated macrophages in human cancers. J Transl Med 9:216. doi:10.1186/14795876-9-216

12. Elez ME, Tabernero J, Geary D, Macarulla T, Kang SP, Kahatt C, Pita AS, Teruel CF, Siguero M, Cullell-Young M, Szyldergemajn S, Ratain MJ (2014) First-in-human phase I study of Lurbinectedin (PM01183) in patients with advanced solid tumors. Clinical cancer research : an official journal of the American Association for Cancer Research 20 (8):2205-2214. doi:10.1158/1078-0432.CCR-13-1880

13. Ratain MJ, Gore L, Szyldergemajn S, Diamond J, Geary D, Fernandez-Teruel C, Soto-Matos A, Sharma M, Jimeno A 23 Phase I study of lurbinectedin (PM01183) 
administered on days (D) 1 \&amp; 8 every 3 weeks (q3wk) in patients (pts) with solid tumors. European Journal of Cancer 50:13-14. doi:10.1016/S0959-8049(14)70149-2

14. Smith TJ, Bohlke K, Lyman GH, Carson KR, Crawford J, Cross SJ, Goldberg JM, Khatcheressian JL, Leighl NB, Perkins CL, Somlo G, Wade JL, Wozniak AJ, Armitage JO (2015) Recommendations for the Use of WBC Growth Factors: American Society of Clinical Oncology Clinical Practice Guideline Update. Journal of Clinical Oncology. doi:10.1200/jco.2015.62.3488

15. Yilmaz B, Kadioglu YY, Aksoy Y (2004) Investigation of the pharmacokinetics of gemcitabine and 2',2'-difluorodeoxyuridine in human plasma by liquid chromatography. Anal Biochem 332 (2):234-237. doi:10.1016/j.ab.2004.05.059

16. Messersmith WA, Jimeno A, Ettinger D, Laheru D, Brahmer J, Lansey D, Khan Y, Donehower RC, Elsayed Y, Zannikos P, Hidalgo M (2008) Phase I trial of weekly trabectedin (ET-743) and gemcitabine in patients with advanced solid tumors. Cancer chemotherapy and pharmacology 63 (1):181-188. doi:10.1007/s00280-008-0733-7

17. Faivre S, Le Chevalier T, Monnerat C, Lokiec F, Novello S, Taieb J, Pautier P, Lhomme C, Ruffie P, Kayitalire L, Armand JP, Raymond E (2002) Phase I-II and pharmacokinetic study of gemcitabine combined with oxaliplatin in patients with advanced non-small-cell lung cancer and ovarian carcinoma. Annals of oncology : official journal of the European Society for Medical Oncology / ESMO 13 (9):14791489

18. Lee M-Y, Jung KS, Kim HS, Lee JY, Lim SH, Kim M, Jung HA, Kim SM, Sun JM, Ahn M-J, Lee J, Park SH, Yi SY, Hwang IG, Lee S-C, Ahn HK, Lim DH, Lee SI, Park KW (2015) Weekly docetaxel and gemcitabine in previously treated metastatic esophageal squamous cell carcinoma. World Journal of Gastroenterology : WJG 21 (14):4268-4274. doi:10.3748/wjg.v21.i14.4268

19. Seidman AD (2004) Gemcitabine and docetaxel in metastatic breast cancer. Oncology (Williston Park) 18 (14 Suppl 12):13-16

20. Johnson DH (2001) Gemcitabine for the treatment of non-small-cell lung cancer. Oncology (Williston Park) 15 (3 Suppl 6):33-39

21. Blackstein M, Vogel CL, Ambinder R, Cowan J, Iglesias J, Melemed A (2002) Gemcitabine as first-line therapy in patients with metastatic breast cancer: a phase II trial. Oncology 62 (1):2-8

22. Pfisterer J, Plante M, Vergote I, du Bois A, Hirte H, Lacave AJ, Wagner U, Stahle A, Stuart G, Kimmig R, Olbricht S, Le T, Emerich J, Kuhn W, Bentley J, Jackisch C, Luck HJ, Rochon J, Zimmermann AH, Eisenhauer E, Ago O, Ncic CTG, Eortc GCG (2006) Gemcitabine plus carboplatin compared with carboplatin in patients with platinum-sensitive recurrent ovarian cancer: an intergroup trial of the AGO-OVAR, the NCIC CTG, and the EORTC GCG. J Clin Oncol 24 (29):4699-4707. doi:10.1200/JCO.2006.06.0913

23. Bria E, Milella M, Gelibter A, Cuppone F, Pino MS, Ruggeri EM, Carlini P, Nistico C, Terzoli E, Cognetti F, Giannarelli D (2007) Gemcitabine-based combinations for inoperable pancreatic cancer: have we made real progress? A meta-analysis of 20 phase 3 trials. Cancer 110 (3):525-533. doi:10.1002/cncr.22809

24. Stinchcombe TE, Socinski MA (2008) Considerations for second-line therapy of non-small cell lung cancer. Oncologist 13 Suppl 1:28-36. doi:10.1634/theoncologist.13S1-28

25. He J, Hu Y, Hu M, Li B (2015) Development of PD-1/PD-L1 Pathway in Tumor Immune Microenvironment and Treatment for Non-Small Cell Lung Cancer. Sci Rep 5:13110. doi:10.1038/srep13110 
26. Cameron L, Solomon B (2015) Treatment of ALK-Rearranged Non-Small Cell Lung Cancer: Recent Progress and Future Directions. Drugs 75 (10):1059-1070. doi:10.1007/s40265-015-0415-9

27. Poveda A, Berton-Rigaud D, Ray-Coquard IL, Alexandre J, Provansal M, Soto A, Kahatt CM, Szyldergemajn SA, Nieto A, Fernandez C, Guerra Alia E, Casado A, Gonzalez-Martin A, Del Campo JM (2014) Lurbinectedin (PM01183), an active compound in platinum-resistant/refractory ovarian cancer (PRROC) patients: Results of a two-stage, controlled phase II study. ASCO Meeting Abstracts 32 (15_suppl):5505

28. Balmaña J, Cruz C, Garber J, Perez Fidalgo JA, Lluch A, Tung N, Antolin S, Fernandez C, Kahatt C, Szyldergemajn S, Soto Matos A, Extremera S, Baselga J, Isakoff SJ (2015) Abstract P3-13-01: Lurbinectedin (PM01183) activity in BRCA1/2associated or unselected metastatic breast cancer. Interim results of an ongoing phase II trial. Cancer Research 75 (9 Supplement):P3-13-01. doi:10.1158/1538-7445.sabcs14p3-13-01 


\section{TABLES}

Table 1. Baseline characteristics of patients.

\begin{tabular}{|c|c|c|}
\hline & $\underset{(n=11)}{\mathbf{R D}}$ & $\begin{array}{c}\text { Total } \\
(n=45)\end{array}$ \\
\hline \multicolumn{3}{|l|}{ Gender } \\
\hline Male & $5(46 \%)$ & $24(53 \%)$ \\
\hline Female & $6(54 \%)$ & $21(47 \%)$ \\
\hline Median age (range) (years) & $56(38-68)$ & $59(37-72)$ \\
\hline \multicolumn{3}{|l|}{ ECOG performance status } \\
\hline 0 & $4(36 \%)$ & $16(36 \%)$ \\
\hline 1 & $7(64 \%)$ & $29(64 \%)$ \\
\hline Median BSA (range) $\left(\mathrm{m}^{2}\right)$ & $1.9(1.6-2.2)$ & $1.8(1.4-2.2)$ \\
\hline Baseline LDH (range) (IU/L) & $224(156-593)$ & $398(134-1618)$ \\
\hline Median albumin (range) (g/dL) & $4.4(3.5-4.8)$ & $4.0(2.6-4.8)$ \\
\hline \multicolumn{3}{|l|}{ Primary tumor } \\
\hline NSCLC & $3(27 \%)$ & $22(49 \%)$ \\
\hline Non-squamous & $2(18 \%)$ & $21(47 \%)$ \\
\hline Squamous & $1(9 \%)$ & $1(2 \%)$ \\
\hline Pancreatic adenocarcinoma & $2(18 \%)$ & $6(13 \%)$ \\
\hline Breast & $1(9 \%)$ & $6(13 \%)$ \\
\hline Triple negative & . & $2(4 \%)$ \\
\hline Hormone receptor-positive and HER2-negative & $1(9 \%)$ & $4(9 \%)$ \\
\hline Ovarian carcinoma & $3(27 \%)$ & $5(11 \%)$ \\
\hline Platinum resistant/refractory & $2(18 \%)$ & $4(9 \%)$ \\
\hline Platinum sensitive & $1(9 \%)$ & $1(2 \%)$ \\
\hline Other ${ }^{a}$ & $2(18 \%)$ & $6(13 \%)$ \\
\hline $\begin{array}{l}\text { Median sum of diameter of target lesions (range) } \\
(\mathrm{mm})\end{array}$ & $52(26-107)$ & $51(11-142)$ \\
\hline PFS of last prior therapy (range) (months) & $3.4(1.6-21.4)$ & $5.8(0.9-33.3)$ \\
\hline $\begin{array}{l}\text { Median number of lines of prior anticancer therapy } \\
\text { for advanced disease (range) }\end{array}$ & $1(1-2)$ & $1(0-3)^{b}$ \\
\hline \multicolumn{3}{|l|}{ Prior treatment } \\
\hline Chemotherapy & $11(100 \%)$ & $42(93 \%)^{b}$ \\
\hline Biological therapy & $5(46 \%)$ & $21(47 \%)$ \\
\hline Investigational drug & $4(36 \%)$ & $11(24 \%)$ \\
\hline
\end{tabular}

RD was PM01183 $3.0 \mathrm{mg}$ FD $\left(1.6 \mathrm{mg} / \mathrm{m}^{2}\right) / \mathrm{gemcitabine} 800 \mathrm{mg} / \mathrm{m}^{2} \mathrm{~d} 1,8 \mathrm{q} 3 \mathrm{wk}$.

a Biliary tract adenocarcinoma $(n=3)$, mesothelioma $(n=2)$ and endometrial adenocarcinoma $(n=1)$.

${ }^{\mathrm{b}}$ Three patients with pancreatic tumors were treated with PM01183/gemcitabine as first-line.

BSA, body surface area; ECOG, Eastern Cooperative Oncology Group; LDH, lactate dehydrogenase; NSCLC, nonsmall cell lung cancer; PFS, progression-free survival; q3wk, every 3 weeks; RD, recommended dose; ULN, upper limit of normal. 
Table 2. Dose escalation scheme and dose-limiting toxicity.

\begin{tabular}{|c|c|c|c|c|}
\hline $\begin{array}{c}\text { PM01183/ } \\
\text { Gemcitabine } \\
\text { dose level }\end{array}$ & $\begin{array}{c}\text { Number of patients } \\
\text { treated/number } \\
\text { evaluable for DLT }\end{array}$ & $\begin{array}{c}\text { Number of } \\
\text { patients } \\
\text { with DLT } \\
\end{array}$ & $\begin{array}{c}\text { \% patients with } \\
\text { DLT/evaluable } \\
\text { patients }(95 \% \mathrm{CI})\end{array}$ & Dose-limiting toxicity \\
\hline $\begin{array}{l}2.5 \mathrm{mg} \mathrm{FD} / \\
800 \mathrm{mg} / \mathrm{m}^{2}\end{array}$ & $4 / 3$ & None & $\begin{array}{c}0 \% \\
(0-71 \%)\end{array}$ & \\
\hline $\begin{array}{l}3.0 \mathrm{mg} \mathrm{FD} / \\
800 \mathrm{mg} / \mathrm{m}^{2} \\
(\mathrm{RD})\end{array}$ & $11 / 11$ & None & $\begin{array}{c}0 \% \\
(0-46 \%)\end{array}$ & \\
\hline $\begin{array}{l}3.5 \mathrm{mg} \mathrm{FD} / \\
800 \mathrm{mg} / \mathrm{m}^{2}\end{array}$ & $21 / 19$ & 6 & $\begin{array}{c}32 \% \\
(13-57 \%)\end{array}$ & $\begin{array}{l}\text { Febrile neutropenia (grade } 4, n=3 \text {; } \\
\text { grade } 3, n=2 \text { ) } \\
\text { Thrombocytopenia (grade } 4, n=4 \text { ) } \\
\text { Hemoptysis (grade } 4, n=1 \text { ) } \\
\text { Treatment-related death }(n=1)\end{array}$ \\
\hline $\begin{array}{l}3.5 \mathrm{mg} \mathrm{FD} / \\
1000 \mathrm{mg} / \mathrm{m}^{2}\end{array}$ & $9 / 6$ & 4 & $\begin{array}{c}67 \% \\
(23-96 \%)\end{array}$ & $\begin{array}{l}\text { Neutropenic infection (grade } 4 \text {, } \\
\mathrm{n}=1 \text { ) } \\
\text { Day-8 infusions omitted } \\
\text { systematically }(\mathrm{n}=1 \text { ) } \\
\text { Febrile neutropenia (grade } 4, \mathrm{n}=1 \text { ) } \\
\text { Thrombocytopenia (grade } 4, \mathrm{n}=2 \text { ) } \\
\text { Neutropenic sepsis (grade } 5, \mathrm{n}=1 \text { ) } \\
\text { Treatment-related death }(\mathrm{n}=1) \text {. }\end{array}$ \\
\hline
\end{tabular}

CI, confidence interval: DLT, dose-limiting toxicity; FD, flat dose; RD, recommended dose. 
Table 3. Laboratory abnormalities and treatment-related (or relationship unknown) adverse events (in $\geq 10 \%$ of patients) at the recommended dose of the PM01183/gemcitabine combination.

\begin{tabular}{|c|c|c|c|c|c|c|c|c|c|c|}
\hline \multirow[b]{2}{*}{ NCI-CTCAE grade } & \multicolumn{5}{|c|}{$\begin{array}{c}\text { Per patient } \\
(n=11)\end{array}$} & \multicolumn{5}{|c|}{$\begin{array}{c}\text { Per cycle } \\
(n=56)\end{array}$} \\
\hline & 1 & 2 & 3 & 4 & Total & 1 & 2 & 3 & 4 & Total \\
\hline \multicolumn{11}{|c|}{ Hematological laboratory abnormalities } \\
\hline Anemia & $2(18 \%)$ & $3(27 \%)$ & $5(46 \%)$ & & $10(91 \%)$ & $29(52 \%)$ & $16(29 \%)$ & $8(15 \%)$ & & $53(95 \%)$ \\
\hline Neutropenia & $3(27 \%)$ & $1(9 \%)$ & $1(9 \%)$ & $5(46 \%)$ & $7(64 \%)$ & $6(11 \%)$ & $7(13 \%)$ & $10(18 \%)$ & $10(18 \%)$ & $33(59 \%)$ \\
\hline Thrombocytopenia & $6(55 \%)$ & $1(9 \%)$ & $2(18 \%)$ & $1(9 \%)$ & $10(91 \%)$ & $19(34 \%)$ & $7(13 \%)$ & $3(5 \%)$ & $1(2 \%)$ & $30(54 \%)$ \\
\hline \multicolumn{11}{|c|}{ Biochemical laboratory abnormalities } \\
\hline ALP increased & $3(27 \%)$ & $1(9 \%)$ & $1(9 \%)$ & . & $5(46 \%)$ & $13(23 \%)$ & $5(9 \%)$ & $1(2 \%)$ & . & $19(34 \%)$ \\
\hline ALT increased & $6(55 \%)$ & $3(27 \%)$ & $2(18 \%)$ & . & $11(100 \%)$ & $39(70 \%)$ & $8(14 \%)$ & $2(4 \%)$ & . & $49(88 \%)$ \\
\hline AST increased & $10(91 \%)$ & & $1(9 \%)$ & . & $11(100 \%)$ & $37(66 \%)$ & $1(2 \%)$ & $1(2 \%)$ & . & $39(70 \%)$ \\
\hline Creatinine increased & $5(46 \%)$ & $3(27 \%)$ & & . & $8(73 \%)$ & $17(30 \%)$ & $3(5 \%)$ & & . & $20(36 \%)$ \\
\hline \multicolumn{11}{|c|}{ Drug-related adverse events } \\
\hline Constipation & $2(18 \%)$ & & & & $2(18 \%)$ & $3(5 \%)$ & & & . & $3(5 \%)$ \\
\hline Decreased appetite & $2(18 \%)$ & $1(9 \%)$ & . & . & $3(27 \%)$ & $5(9 \%)$ & $1(2 \%)$ & . & . & $6(11 \%)$ \\
\hline Dysgeusia & $3(27 \%)$ & rete & . & . & $3(27 \%)$ & $5(9 \%)$ & . & 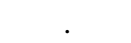 & . & $5(9 \%)$ \\
\hline Edema & $2(18 \%)$ & & & . & $2(18 \%)$ & $2(4 \%)$ & 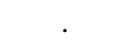 & 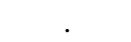 & . & $2(4 \%)$ \\
\hline Fatigue & $2(18 \%)$ & $4(36 \%)$ & $1(9 \%)$ & . & $7(64 \%)$ & $14(25 \%)$ & $7(13 \%)$ & $1(2 \%)$ & . & $22(39 \%)$ \\
\hline Influenza-like illness & & $2(18 \%)$ & . & . & $2(18 \%)$ & $1(2 \%)$ & $2(4 \%)$ & & . & $3(5 \%)$ \\
\hline Malaise & $1(9 \%)$ & $1(9 \%)$ & . & . & $2(18 \%)$ & $1(2 \%)$ & $1(2 \%)$ & $\cdot$ & . & $2(4 \%)$ \\
\hline Nausea & $4(36 \%)$ & $2(18 \%)$ & . & . & $6(55 \%)$ & $9(16 \%)$ & $3(5 \%)$ & . & . & $12(21 \%)$ \\
\hline $\begin{array}{l}\text { Peripheral sensory } \\
\text { neuropathy }\end{array}$ & $4(36 \%)$ & , & . & . & $4(36 \%)$ & $6(11 \%)$ & . & & . & $6(11 \%)$ \\
\hline Pyrexia & $2(18 \%)$ & . & & & $2(18 \%)$ & $3(5 \%)$ & . & & . & $3(5 \%)$ \\
\hline Rash & $2(18 \%)$ & 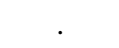 & $1(9 \%)$ & . & $3(27 \%)$ & $3(5 \%)$ & . & $1(2 \%)$ & . & $4(7 \%)$ \\
\hline Stomatitis & $2(18 \%)$ & & . & . & $2(18 \%)$ & $3(5 \%)$ & . & . & . & $3(5 \%)$ \\
\hline Vomiting & $2(18 \%)$ & $2(18 \%)$ & & & $4(36 \%)$ & $4(7 \%)$ & $2(4 \%)$ & & . & $6(11 \%)$ \\
\hline
\end{tabular}

The number and percentage of patients/cycles with each adverse event is specified.

Hematological and biochemical abnormalities are shown regardless of relationship to treatment.

RD was PM01183 $3.0 \mathrm{mg}$ FD $\left(1.6 \mathrm{mg} / \mathrm{m}^{2}\right) /$ gemcitabine $800 \mathrm{mg} / \mathrm{m}^{2} \mathrm{~d} 1,8 \mathrm{q} 3 \mathrm{wk}$.

ALP, alkaline phosphatase; ALT, alanine aminotransferase; AST, aspartate aminotransferase; FD, flat dose; NCI-CTCAE, National Cancer Institute Common Terminology Criteria for Adverse Events; q3wk, every 3 weeks; RD, recommended dose. 
Table 4. Overall efficacy as per RECIST v 1.1 by tumor type in evaluable patients with $95 \%$ confidence interval estimates $(n=38)$.

\begin{tabular}{|c|c|c|c|c|c|c|c|c|c|c|c|}
\hline & & \multicolumn{2}{|c|}{$\begin{array}{c}\text { NSCLC } \\
(n=17)\end{array}$} & \multicolumn{2}{|c|}{$\begin{array}{c}\text { Pancreas } \\
(n=6)\end{array}$} & \multicolumn{2}{|c|}{$\begin{array}{c}\text { Breast } \\
(n=6)\end{array}$} & \multicolumn{2}{|c|}{$\begin{array}{l}\text { Ovarian } \\
(\mathrm{n}=5)\end{array}$} & \multicolumn{2}{|c|}{$\begin{array}{l}\text { Other }^{\text {a }} \\
(n=4)\end{array}$} \\
\hline & & $\mathbf{n}$ & $\%$ & $\mathbf{n}$ & $\%$ & $\mathbf{n}$ & $\%$ & $\mathbf{n}$ & $\%$ & $\mathbf{n}$ & $\%$ \\
\hline \multicolumn{2}{|l|}{ CR } & 1 & 6 & . & . & . & . & . & . & . & . \\
\hline \multicolumn{2}{|l|}{ PR } & 4 & 24 & 1 & 17 & 1 & 17 & 2 & 40 & . & . \\
\hline \multirow[t]{2}{*}{ SD } & $\geq 4$ months & 5 & 29 & 1 & 17 & 3 & 50 & 1 & 20 & 1 & 25 \\
\hline & $<4$ months & 4 & 24 & 2 & 33 & 1 & 17 & . & . & 3 & 75 \\
\hline \multicolumn{2}{|l|}{ PD } & 3 & 18 & 2 & 33 & 1 & 17 & 2 & 40 & . & . \\
\hline \multicolumn{2}{|c|}{$\begin{array}{l}\text { ORR b } 95 \% \text { CI } \\
\text { (range) }\end{array}$} & \multicolumn{2}{|c|}{$\begin{array}{c}29 \% \\
(10-56 \%)\end{array}$} & \multicolumn{2}{|c|}{$\begin{array}{c}17 \% \\
(0-64 \%)\end{array}$} & \multicolumn{2}{|c|}{$\begin{array}{c}17 \% \\
(0-64 \%)\end{array}$} & \multicolumn{2}{|c|}{$\begin{array}{c}40 \% \\
(5-85 \%)\end{array}$} & \multicolumn{2}{|c|}{$\begin{array}{c}0 \% \\
(0-60 \%)\end{array}$} \\
\hline
\end{tabular}


Table 5. Non-compartmental pharmacokinetic parameters of PM01183, gemcitabine, and its metabolite, dFdU, by dose level on Day 1 of Cycle 1 .

\begin{tabular}{|c|c|c|c|c|}
\hline & \multicolumn{4}{|c|}{ PM01183 mg FD / gemcitabine $\left(\mathrm{mg} / \mathrm{m}^{2}\right)$} \\
\hline & $2.5 / 800$ & $3.0 / 800$ (RD) & $3.5 / 800$ & $3.5 / 1000$ \\
\hline PM01183 & $\mathrm{n}=2$ & $\mathrm{n}=10$ & $\mathrm{n}=20$ & $\mathrm{n}=8$ \\
\hline Dose $\left(\mathrm{mg} / \mathrm{m}^{2}\right)$ & $1.6(0.0)$ & $1.7(0.2)$ & $1.9(0.2)$ & $2.1(0.3)$ \\
\hline$C_{\max }(\mu g / L)$ & $92.3(90.2)$ & $65.6(28.6)$ & $75.4(25.4)$ & $78.4(34.6)$ \\
\hline $\operatorname{AUC}(h * \mu g / L)$ & $252.2(132.4)$ & $304.5(168.6)$ & $411.1(311.9)$ & $495.8(278.2)$ \\
\hline HL (h) & $47.6(1.9)$ & $48.8(19.1)$ & $51.0(19.4)$ & $53.1(24.8)$ \\
\hline CL $(\mathbf{L} / \mathbf{h})$ & $11.5(6.0)$ & $13.4(8.2)$ & $11.6(5.7)$ & $9.4(5.3)$ \\
\hline $\mathbf{V}_{\text {ss }}(\mathbf{L})$ & $503.9(508.7)$ & $532.1(245.5)$ & $499.9(292.2)$ & $512.8(360.2)$ \\
\hline $\mathbf{V}_{\mathbf{z}}(\mathbf{L})$ & $797.3(446.1)$ & $886.7(478)$ & $838.1(527.6)$ & $714.3(527.8)$ \\
\hline Gemcitabine & $\mathrm{n}=2$ & $\mathrm{n}=10$ & $\mathrm{n}=20$ & $\mathrm{n}=8$ \\
\hline$C_{\max }(\mu \mathrm{g} / \mathrm{mL})$ & $24.9(17.5)$ & $13.9(8.5)$ & $12.9(6.8)$ & $13.2(6.6)$ \\
\hline $\operatorname{AUC}\left(h^{*} \mu \mathrm{g} / \mathrm{mL}\right)$ & $9.5(5.7)$ & $6.3(3.5)$ & $5.8(2.6)$ & $6.7(2.9)$ \\
\hline HL (h) & $0.5(0.1)$ & $0.2(0.1)$ & $0.3(0.2)$ & $0.3(0.1)$ \\
\hline CL $(\mathbf{L} / \mathbf{h})$ & $164.0(95.9)$ & $321.2(277.8)$ & $324.6(208.7)$ & $362.2(306.4)$ \\
\hline $\mathbf{V}_{\text {ss }}(\mathbf{L})$ & $60.1(46.6)$ & $119.9(119.8)$ & $118.6(78.8)$ & $137.2(119.0)$ \\
\hline $\mathbf{V}_{\mathbf{z}}(\mathbf{L})$ & $116.9(41.1)$ & $105.7(84.9)$ & $147.8(112.8)$ & $185.3(222.1)$ \\
\hline dFdU & $\mathrm{n}=4$ & $\mathrm{n}=11$ & $\mathrm{n}=22$ & $\mathrm{n}=8$ \\
\hline$C_{\max }(\mu \mathrm{g} / \mathrm{mL})$ & $28.9(8.7)$ & $24.4(2)$ & $26.5(5.3)$ & $34.8(8.7)$ \\
\hline $\operatorname{AUC}(h * \mu g / m L)$ & $275.7(83.5)$ & $277.0(96.7)$ & $284.4(69.4)$ & $364.3(131.7)$ \\
\hline HL (h) & $20.0(5.6)$ & $20.3(3.9)$ & $21.2(4.2)$ & $18.2(3.3)$ \\
\hline CL $(\mathrm{L} / \mathrm{h})$ & $5.5(1.6)$ & $5.6(1.4)$ & $5.4(1.6)$ & $5.6(2.8)$ \\
\hline $\mathbf{V}_{\text {ss }}(\mathbf{L})$ & $139.3(40.2)$ & $140.8(32.1)$ & $145.5(36.3)$ & $124.5(49.3)$ \\
\hline $\mathbf{V}_{\mathbf{z}}(\mathbf{L})$ & $152.8(37.3)$ & $161.5(42.6)$ & $163.2(44.8)$ & $141.0(64.4)$ \\
\hline
\end{tabular}

Values are expressed as mean (standard deviation).

AUC, area under the concentration-time curve from time zero to infinity; CL, total body clearance; $\mathrm{C}_{\max }$, maximum plasma concentration; FD, flat dose; HL, terminal half-life; RD, recommended dose; $\mathrm{V}_{\mathrm{ss}}$, volume of distribution at steady-state; $\mathrm{V}_{\mathrm{z}}$, volume of distribution based on the terminal half-life. 